\title{
First report of Fusarium avenaceum causing branch canker on pear in Turkey
}

\author{
Zühtü Polat $^{1} \cdot$ Mehmet Akif Gültekin ${ }^{1} \cdot$ Gülsüm Palacıoğlu ${ }^{2,3} \cdot$ Mehmet Emin Akçay ${ }^{1} \cdot$ Harun Bayraktar ${ }^{2} \mathbb{C}$
}

Received: 20 August 2021 / Accepted: 7 January 2022 / Published online: 17 January 2022

(c) The Author(s) under exclusive licence to Società Italiana di Patologia Vegetale (S.I.Pa.V.) 2022

Keyword Fusarium avenaceum - Pyrus communis · branch canker

Pear (Pyrus communis) is an important fruit crop in Turkey. In May 2021, canker lesions were observed in pruning wounds on approximately $70 \%$ of the pear trees cultivar Deveci in a five-year-old orchard in Bursa province, Turkey. Disease symptoms were twig blight, brownish bark and branch canker. Twenty small pieces from branch lesions were surface disinfected with $1 \% \mathrm{NaOCl}$ solution for $3 \mathrm{~min}$ and placed on potato dextrose agar. Petri dishes were incubated for 10 days at $23^{\circ} \mathrm{C}$. All colonies were Fusarium-like with the production of a yellow to rose pigment and a dark pink to red reverse with abundant white aerial mycelium. Macroconidia formed on sporodochia were slender, slightly curved, usually 3 to 5 septate, with a tapering apical cell and a foot-shaped basal cell and measured 40-80 $\times 3.5-5.5 \mu \mathrm{m}$ $(\mathrm{n}=30)$. Microconidia and chlamydospores were not observed. The pathogen was identified as Fusarium spp. (Leslie and Summerell 2006). For further identification, EF1a and RPB2 genes of the isolate Fav2 were sequenced with primers EF1/EF2 and RPB1/RPB2 (O'Donnell et al. 2010; Staats et al. 2005) and deposited in GenBank (EF1a: MZ821072, RPB2: MZ821073). Blastn analysis suggested 99.38-100\% similarity to $F$. avenaceum strain NRRL 25,128 (EF1a: MH582378, RPB2: MH582355). Phylogenetic analysis showed the close genetic relationship among $F$. avenaceum. To confirm Koch's postulates, four mm plugs of the pathogen culture were applied to the same size bark wounds on the middle point of six branches. The inoculated branches

Harun Bayraktar

bayrakta@agri.ankara.edu.tr

1 Atatürk Central Horticultural Research Institute, 77102 Yalova, Turkey

2 Department of Plant Protection, Faculty of Agriculture, Ankara University, 06110 Ankara, Turkey

3 Department of Plant Protection, Faculty of Agriculture, Şırnak University, Şırnak, Turkey were sealed with Parafilm and incubated for three weeks at $25{ }^{\circ} \mathrm{C}$ in moist chambers. All the inoculated branches showed dark-brown necrotic lesions on inoculation point. The fungus was re-isolated from the lesions and confirmed to be $F$. avenaceum. Control plants inoculated with PDA plugs remained symptomless. To our knowledge, this is the first report of branch canker caused by $F$. avenaceum on pear in Turkey.

\section{Declarations}

Ethical statement This article does not contain any studies with human participants or animals.

Conflict of interest All authors declare that they have no conflict of interests.

\section{References}

Leslie JF, Summerell BA (2006) The Fusarium laboratory manual. Blackwell Publishing, Iowa, USA

O'Donnell K, Sutton DA, Rinaldi MG, Sarver BA, Balajee SA, Schroers HJ, Summerbell RC, Robert VA, Crous PW, Zhang N, Aoki T (2010) Internet-accessible DNA sequence database for identifying fusaria from human and animal infections. J Clin Microbiol 48:3708-3718

Staats M, van Baarlen P, van Kan JA (2005) Molecular phylogeny of the plant pathogenic genus Botrytis and the evolution of host specificity. Mol Biol Evol 22:333-346

Publisher's Note Springer Nature remains neutral with regard to jurisdictional claims in published maps and institutional affiliations. 